\title{
PERENCANAAN ASUHAN KEPERAWATAN DALAM MENENTUKAN PRIORITAS, TUJUAN, DAN RENCANA TINDAKAN KEPERAWATAN
}

\section{PRIMA SITEPU}

\section{Primasitepu01@gmail.com}

\section{LATAR BELAKANG}

Perencanaan keperawatan atau biasa disebut intervensi keperawatan merupakan bagian dari proses keperawatan yaitu tahap ketiga. Setelah mengetahui diagnose keperawatan yang tepat untuk pasien, selanjutnya perawat menentukan dan memepersiapkan perencanaan keperawatan untuk diiimplementasikan ketika memberi asuhan keperawatan. Perencanaan keperawatan yang dipersipakan oleh perawat tentunya harus berhbungan dengan kondisi pasien berdasarkan pengkajian dan diagnose keperawatan.

Hal penting yang perlu diketahui terkait perencanaan keperawatan ini perawat perlu menentukan prioritas, menulis tujuan, dan merencanakan tindakan keperawatan tang akan dilakukan. Pada tahap menentukan prioritas perawat menentukaan masalah pasien yang 1 terlebih dahulu diatasi. Diantara diagnosa keperawatan yang sudah ditentukan perawat harus bisa memprioritaskan hal yang terlebih dahulu dilakukan segera. Pada tahap menuliskan tujuan, perawat menuliskan hasil yang perawat harapkan agar tercapai. Tujuan keperawatan yang jelas akan menunjukkan hasil dari tindakan keperawatan.

Pernyataan tujuan harus merupakann perilaku pasien yang memeperlihatkan berkuragnya masalah yang dialami pasien. Tujuan juga harus realistis dan sejlaan dan menyokong atau membantu perawatan lain yang diterima pasien. Proses keperawatan sebagai alat bagi perawat untuk melaksanakan asuhan keperawatan yang dilakukan pada pasien memiliki arti penting bagi kedua belah pihak yaitu perawat dan klien. Sebagai seorang perawat proses keperawatan dapat digunakan sebagai pedoman dalam pemecahan masalah klien, dapat menunjukkan profesi yang memiliki profesionalitas yang tinggi, serta dapat memberikan kebebasan pada klien untuk mendapatkan pelayanan yang cukup sesuai dengan kebutuhannya, sehingga dapat diraskan manfaatnya baik dari perawat maupun klien. manfaat tersebut antara lain dapat meningkatkan kemandirian pada perawat dalam melaksanakan tugasnya karena didalam proses keperawatan terdapat metode ilmiah 
keperawatan yang berupa langkah-langkah proses keperawatan, akan dapat meningkatkan kepercayaan diri perawat dalam melaksanakan tugas, karena klien akan merasakan kepuasan setelah dilakukan asuhan keperawatan dengan pendekatan proses keperawatan, akan dapat selalu meningkatkan kemampuan intelektual dan teknikal dalam tindakan keperawatan karena melalui proses keperawatan dituntut mampu memecahkan masalah yang baru sesuai dengan masalah yang dialami klien, sehingga akan timbul perasaan akan kepuasan kerja. Dengan proses keperawatan, rasa tanggung jawab dan tanggung gugat bagi perawat itu dapat dimiliki dan dapat digunakan dalam tindakan-tindakan yang merugikan atau menghindari adanya tindakan yang legal.

\section{METODE}

Metode dalam pembuatan kajian tersebut yaitu literasi. Saya membaca dari berbagai referensi berupa buku dan jurnal. Melalui metode literature ini saya memahami dan mengidentikasi perencanaan keperawatan, bagaimana membuat prioritas masalah, membuat tujuan dan kriteria hasil, memutuskan perencanan keperawatan yang akan diimplementasikan.

\section{HASIL}

Berdasarkan hasil literature saya, bahwa perawat yang professional dalam memberikan asuhan tentu akan memepersiapkan terlebih dahulu perencanaan yang akan diimplementasikan. Semua tindakan pelayanan dilakukan berdasarkan proses keperawatan. Pengetahuan dan motivasi perawat juga berpengaruh, salah satu literature saya menunjukkan bahwa perawat yang memiliki pengetahuan yang tinggi mengenai proses keperawatan termasuk intervensi keperawatan akan dapat memeberikan pelayanan yang semakin baik kepada pasien.

Semakin tinggi pengetahuan perawat maka akan semakin baik pula perawat menerapkan perencanaan yang telah dipersiapkan.

Ini menunjukkan pengetahuan yang dimiliki perawat menentukan ketepatan perawat dalam memberikan pelayanan. Persepsi perawat juga memberikan pengaruh bahwa dengan persepsi negative tentu akan membuat asuhan yang akan diberikan perawat akan kurang berhasil. Perawat perlu meyakinkan dirinya terhdaap tindakan yang akan dilakukan untuk memperoleh hasil yang baik. Ini akan bermanfaat untuk memeberikan pelayanan yang baik dan tepat pada pasien. Dari banyak masalah yang dialami pasien, perawat perlu mengidentifikasi masalah yang terlebih dahulu diatasi. Intervensi yang dipersiapkan perawat tentunya lebih dari satu oleh 3 karena itu perawat perlu membuat prioritas terlbih dahulu tindakan yang pertama kali dilakukan. 


\section{PEMBAHASAN}

Intervensi keperawatan adalah preskripsi untuk perilaku spesifik yang diharapkan dari pasien dan / atau tindakan yang harus dilakukan oleh perawat tindakan / intervensi keperawatan dipilih untuk membantu pasien dalam mencapai hasil pasien yang diharapkan dan tujuan pemulangan harapannya adalah bahwa perilaku yang dipreskripsikan akan menguntungkan pasien dan keluarga dalam cara yang dapat diprediksi , yang berhubungan dengan masalah yang diidentifikasidan tujuan yang telah dipilih. Intervensi ini bermaksud mengindividualkan perawatan dengan memenuhi kebutuhan spesifik pasien serta harus menyertakan kekuatankekuatan pasien yang telah diidentifikasi bila memungkinkan.

\section{A. Tahap Perencanaan}

Tahap perencanaan merupakan suatu proses penyusunan berbagai intervensi keperawatan yang dibutuhkan untuk mencegah, menurunkan atau mengurangi masalahmasalah klien. Perencanaan ini merupakan langkah ketiga dalam membuat suatu proses keperawatan. Dalam menentukan tahap perencanaan bagi perawat diperlukan berbagai pengetahuan dan keterampilan diantaranya pengetahuan tentang kekuatan dan kelemahan klien, nilai dan kepercayaan klien, batasan praktek keperawatan, peran dari tenaga kesehatan lainnya , kemampuan dalam memecahkan masalah, mengambil keputusan, menulis tujuan serta memilih dan membuat strategi keperawatan yang aman dalam memenuhi tujuan, menulis instruksi keperawatan serta kemampuan dalam melaksanakan kerja sama dengan tingkat kesehatan lain.

B. Sumber Data Sebelum menuliskan rencana tindakan keperawatan, kaji ulang semua data yang ada sumber data yang memuaskan meliputi:

1. Pengkajian sewaktu klien masuk rumah sakit.

2. Diagnosa perawatan waktu masuk rumah sakit.

3. Keluhan utama klien atau alasan dalam berhubungan dengan pelayanan kesehatan.

4. Laboratorium ritme.

5. Latar belakang sosial budaya.

6. Riwayat kesehatan dan pemeriksaan fisik.

7. Observasi dari tim kesehatan lain. 


\section{Langkah-langkah}

Perencanaan Pada tahap perencanan dapat dilaksanakan dengan berbagai kegiatan, yaitu sebagai berikut:

\section{Penentuan prioritas diagnosis}

Penentuan prioritas diagnosis ini dilakukan pada tahap perencanaan setelah tahap diagnosis keperawatan. Dengan menentukan diagnosis keperawatan, maka dapat diketahui diagnosis mana yang akan dilakukan atau diatasi pertama kali atau yang segera dilakukan. Dalam menentukan prioritas terdapat beberapa pendapat urutan prioritas, di antaranya:

a. Berdasarkan tingkat kegawatan (mengancam jiwa) Penentuan prioritas berdasarkan tingkat kegawatan (mengancam jiwa) yang dilatarbelakangi dari prinsip pertolongan pertama yaitu dengan membagi beberapa prioritas diantaranya prioritas tinggi, prioritas sedang, dan prioritas rendah.

1) Prioritas tinggi _ prioritas yang mencerminkan situasi yang mengancam kehidupan (nyawa seseorang) sehingga perlu dilakukan tindakan terlebih dahulu seperti masalah pembersihan jalan nafas.

2) Prioritas sedang _ prioritas ini menggambarkan situasi yang tidak gawat dan tidak mengancam hidup klien seperti masalah personal higiene.

3) Prioritas rendah _ prioritas yang menggambarkan situasi yang tidak berhubungan langsung dengan prognosis dari suatu penyakit yang secara spesifik seperti masalah keuangan dan lainnya.

\section{b. Berdasarkan kebutuhan Maslow}

Maslow menentukan prioritas diagnosis yang akan direncanakan berdasarkan urutan kebutuhan dasar manusia, diantaranya: Kebutuhan fisiologis, meliputi masalah respirasi, sirkulasi, suhu, nutrisi, nyeri, cairan, perawatan kulit, mobilisasi, dan eliminasi. Kebutuhan keselamatan dan keamanan, meliputi masalah lingkungan, kondisi tempat tinggal, perlindungan, pakaian, bebas dari infeksi dan rasa takut. Kebutuhan mencintai dan dicintai, meliputi masalah kasih sayang, seksualitas, afiliasi dalam kelompok, dan hubungan antar manusia. Kebutuhan harga diri, meliputi masalah respek dari keluarga, perasaan menghargai diri sendiri. Kebutuhan aktualisasi diri, meliputi masalah kepuasan terhadap lingkungan. 
2. Penentuan tujuan dan hasil yang diharapkan

Tujuan merupakan sinonim dari kriteria hasil yang mempunyai komponen sebagai berikut:

S (Subjek)

P (Predikat

K (Kriteria)

K (Kondisi

W (Waktu)

dengan penjabaran sebagai berikut:

S: Perilaku pasien yang diamati.

P: Kondisi yang melengkapi pasien.

$\mathrm{K}$ : Kata kerja yang dapat diukur atau untuk meentukan tercapainya tujuan.

K: Sesuatu yang menyebabkan asuhan diberikan.

W: Waktu yang ingin di capai.

3. Menentukan rencana tindakan

Untuk memudahkan dalam menentukan rencana tindakan, maka ada beberapa persyaratan dalam menuliskan rencana tindakan diantaranya harus terdapat unsur tanggal, kata kerja yang dapat diukur yang dapat dilihat, dirasa dan didengar, adanya subjek, hasil, target tanggal dan tanda tangan perawat. Perawatan dan pengobatan dirancang untuk membantu pencapaian satu atau lebih dari tujuan perawatan sehingga dapat mengurangi, mencegah atau menghilangkan dari masalah pasien.

D. Tipe Intruksi Perawatan dalam Merencanakan Tindakan

Dalam memberikan instruksi keperawatan ada empat tipe intruksi yang digunakan:

1. Tipe Diagnostik _ tipe ini menilai kemungkinan klien ke arah pencapain kriteria hasil dengan observasi secara langsung.

2. Tipe Terapeutik _ mengambarkan tindakan yang dilakukan oleh perawat secara langsung untuk mengurangi, memperbaiki dan mencegah kemungkinan masalah. 
3. Tipe Penyuluhan _ digunakan untuk meningkatkan perawatan diri pasien dengan membantu klien untuk memperoleh tingkah laku individu yang mempermudah pemecahan masalah.

4. Tipe Rujukan _ menggambarkan peran perawat sebagai koordinator dan manager dalam perawatan klien dalam anggota tim kesehatan.

E. Perbedaan Rencana Tindakan Keperawatan dan Tindakan Medis

Menurut Carpenito (2000), rencana tindakan adalah rencana yang disusun oleh perawat untuk kepentingan tindakan keperawatan bagi perawat yang menulis dan perawat lainnya.

Sedangkan rencana tindakan pelimpahan (delegasi) adalah rencana yang disusun oleh dokter untuk dilaksanakan oleh staf perawat.

Program atau perintah dokter adalah bukan perintah untuk perawat, tetapi perintah ditujukan kepada klien yang tindakannya dilaksanakan oleh perawat. Kedua intervensi tersebut memerlukan suatu pengambilan keputusan yang independen, karena secara hukum perawat harus menentukan apakah memang sudah selesai untuk melaksanakan suatu tindakan berdasarkan standar praktik.

Rencana tindakan medis biasanya difokuskan pada kegiatan yang berhubungan dengan diagnostik dan pengobatan berdasarkan kondisi klien. Tindakan tersebut didelegasikan kepada perawat dan tenaga kesehatan lainnya. Tindakan medis sering meliputi pengobatan, uji diagnostik, diet dan pemberian obat.

Rencana tindakan keperawatan ditujukan pada kegiatan yang berhubungan dengan promosi, mempertahankan atau menjaga kesehatan klien. Rencana tindakan tersebut bisa dikategorikan menjadi 3, yaitu:

1. Dependen yaitu tindakan keperawatan atas dasar rujukan dari profesi lain. seperti ahli gizi, physiotherapies, psikolog dan sebagainya.

2. Interdependen yaitu suatu kegiatan yang memerlukan suatu kerja sama dengan tenaga kesehatan lainnya misalnya tenaga soaial, ahli gizi, fisioterapi dan dokter.

3. Independen Adalah suatu kegiatan yang di laksanakan oleh perawat tanpa petunjuk dan perintah dari dokter atau tenaga kesehatan lainnya. Tipe tindakan independent keperawatan ada 4 yaitu: 
1). Tindakan Diagnostik

a. Wawancara dengan klien

b. Observasidan pemeriksaan fisik

c. Melakukan pemeriksaan laboratorium sederhana, misalnya HB dan membaca hasil dari pemeriksaan laboratorium tersebut.

2). Tindakan terapeutik Tindakan untuk mencegah, mengurangi, dan mengatasi masalah klien. Misalnya: Untuk mencegah gangguan integritas kulit dengan melakukan mobilisasi dan memberikan bantal air pada bagian tubuh yang tertekan.

3). Tindakan Edukatif Tindakan ini untuk merubah perilaku klien melalui promosi kesehatan dan pendidikan kesehatan kepada klien. Misalnya: Perawat mengajarkan kepada klien cara injeksi insulin.

4). Tindakan Merujuk Tindakan kerja sama dengan tim kesehatan lainnya.

\section{PENUTUP}

Perencanaan keperawatan yang dipersiapkan oleh perawat harus berhubungan dengan kondisi pasien berdasarkan pengkajian dan diagnose keperawatan. Perencanaan keperawatan menjadi dasar perawat dalam mengimplementasikan tindakan yang akan dilakukan.

Rencana keperawatan yang akan disusun harus mempunyai beberapa komponen, yaitu prioritas masalah, kriteria hasil, rencana intervensi, dan pendokumentasi. Komponenkomponen tersebut sangat membantu pada proses evaluasi keberhasilan asuhan keperawatan yang telah diimplementasikan. Tujuan dari perencanaan SDM keperawatan antara lain:

1) Menentukan kualitas dan kuantitas tenaga keperawatan.

2) The right man on the right place and the right man on the right job (efektivitas dan efisiensi).

3) Menjamin tersedianya tenaga keperawatan masa sekarang maupun masa mendatang.

4) Menghindari tumpang tindih pelaksanaan tugas.

5) Mempermudah koordinasi, integrasi, dan sinkronisasi (KIS)

6) Menjadi pedoman dalam menetapkan program penarikan, seleksi, pengembangan, kompensasi, pengintegrasian, pemeliharaan, kedisiplinan, dan pemberhentian karyawan. 
7) Menjadi pedoman dalam melaksanakan mutasi dan pensiun tenaga keperawatan

\section{REFERENSI}

Aini, D. N. (2018). Hubungan Kualitas Pelayanan Keperawatan dengan Tingkat Kepuasan Pasien Rawat Inap di RSUD DR. H. SOEWONDO KENDAL. Jurnal Ners Widya Husada Semarang, 2.

Aini, N. (2018). Model Keperawatan beserta aplikasinya dalam keperawatan. Malang: Universitas Muhammadiyah Malang

Bandiyah, S. (2017). Ketrampilan Dasar Keperawatan. Yogyakarta. Nuha Medika

Butar-Butar, J., \& Simamora, R. H. (2016). Hubungan Mutu Pelayanan Keperawatan dengan Tingkat Kepuasan Pasien Rawat Inap di RSUD Pandan Kabupaten Tapanuli Tengah. Jurnal Ners Indonesia, 6(1), 50-63.

Simamora, R. H. (2005). Hubungan Persepsi Perawat Pelaksana Terhadap Penerapan Fungsi Pengorganisasian Yang Dilakukan Oleh Kepala Ruangan Dengan Kinerjanya Diruang Rawat Inap RSUD Koja Jakarta Utara (Doctoral dissertation, Tesis FIK UI, Tidak dipublikasikan).

Carpenito, \& Juall, L. (1999). Rencana Asuhan \& Dokumentasi Keperawatan. (Y. Asih, Ed.) Jakarta: EGC.

Dwidiyanti, M. (2014). Intervensi Keperawatan Holistik Program SOWAN Melalui Target Sehat mandiri pada Pasien TB paru. In PROSIDING SEMINAR NASIONAL \& INTERNASIONAL (Vol. 2, No. 1).

Efendi, N. F. (2015). Pendidikan dalam keperawatan. Surabaya: Salemba Medika Kasim, M., \& Abduroof, M. (2016, Mei). Peningakatan Kualitas Pelayanan dan Pendokumentasian Asuhan Keperawataqn dengan Metode TIM. Nurseline Journal, 1, 62-72.

Rezkiki, F., \& Ilfa, A. (2018). Pengaruh Supervisi Terhadap Kelengkapan Dokumentasi Asuhan Keperawatan Di Ruangan Non Bedah. Real in Nursing Journal, 1(2), 67-76.

Siahaan, J. V., Siagian, A., \& Bukit, E. K. (2018). Pengaruh pelatihan ronde keperawatan terhadap kinerja perawat dalam asuhan keperawatan di rs royal prima medan. Jumantik (Jurnal Ilmiah Penelitian Kesehatan), 3(1), 1-15. 
Tarwoto, \& Wartonah. (2010). Kebutuhan Dasar Manusia dan Proses Keperawatan. Jakarta: Salemba Medika 